\title{
Diversity and abundance of solitary and primitively eusocial bees in an urban centre: a case study from Northampton (England)
}

\author{
Muzafar Hussain Sirohi ${ }^{1,3}$ Janet Jackson ${ }^{1}$ Mike Edwards ${ }^{2}$ Jeff Ollerton ${ }^{1}$ \\ 1 University of Northampton, Northampton, UK \\ 2 Lea-side, Carron Lane, Midhurst GU29 9LB, UK \\ 3 Shah Abdul Latif University, Khairpur, Pakistan
}

Email : muzafar.hussain@northampton.ac.uk

\begin{abstract}
The apparent reduction of solitary and primitively eusocial bees populations has remained a huge concern over the past few decades and urbanisation is considered as one of the factors affecting bees at different scales depending on bee guild. As urbanisation is increasing globally it necessitates more research to understand the complex community dynamics of solitary and primitively eusocial bees in urban settings. We investigated the urban core of a British town for diversity and abundance of solitary bees using standardized methods, and compared the results with nearby meadows and nature reserves. The study recorded 48 species within the town, about $22 \%$ of the total species and $58 \%$ of the genera of solitary bees in the United Kingdom. Furthermore we found the urban core to be more diverse and abundant in solitary and primitively eusocial bees compared to the meadows and nature re-serves. Of particular note was an urban record of the nationally rare Red Data Book species Coelioxys quadridentata and its host Anthophora quadrimaculata. This research demonstrates that urban settings can contribute significantly to the conservation of solitary and primitively eusocial bees in Britain.
\end{abstract}

Keywords Biodiversity_Solitary bees_Pollinator decline _ Species richness _ Urbanisation _ Northampton

Cite as:

Sirohi, M. H., Jackson, J., Edwards, M., and Ollerton, J. (2015) Diversity and abundance of solitary and primitively eusocial bees in an urban centre: a case study from Northampton (England). Journal of Insect Conservation: Volume 19, Issue 3 , Page 487-500 


\section{Introduction}

Biodiversity is one of the essential prerequisites that sustain human society; however, it is nevertheless declining through our activities (Butchart et al. 2010). These are resulting in a 1-10\% loss of biodiversity per decade (Wilson 1999). The recent report by the Natural Capital Committee (NCC) expressed concern over ongoing loss of biodiversity in Britain (Defra 2013) which results in the degradation of ecosystems. A significant example of this conflict between requirement and loss is biotic pollination. An estimated $87.5 \%$ of wild flowering plant species use animals as pollinators (Ollerton et al. 2011\} and fruit or seed set of three quarters of the world's main food crop types are increased by animal pollination (Klein et al. 2007). Wild bees (Hymenoptera) are one of the major pollinators of angiosperms (Moldenke 1976; Simpson 1977; Klein et al. 2007) but their diversity and abundance is generally reduced in many regions (Frankie et al. 2009; Grixti et al. 2009; Potts et al. 2010; Leonhardt et al. 2013; Ollerton et al. 2014). There are many potential drivers which may affect wild pollinator abundance in particular. Among the most important ones are land use changes and fragmentation (Goulson et al. 2008; Winfree et al. 2009), environmental pollution and pesticides (Kevan et al. 1997; Rortais et al. 2005), alien species including both, plants and pollinators (Thomson 2006; Stout and Morales 2009), climate change (Dormann et al. 2008), and decreased resource diversity (Biesmeijer et al. 2006). This, however, applies more to the specialist species which require a particular habitat and depend on a selected range of flowers for diet and pollen. The species having a wide range of floral choice and nesting requirements generally do well by switching to alternative resources.

An estimated 272 species of bees live in a variety of landscapes in the United Kingdom (BWARS 2013a). The majority of these are non-social, "'solitary" species, or primitively eusocial with no morphological differences between castes. However it is the social genera Bombus and Apis, which make up $<10 \%$ of British bee diversity, upon which research has been most focused (Goulson et al. 2008; EFSA 2014). Data from the other bees are fragmentary because of the lack of coordinated programmes (Potts et al. 2010). Analysing records of native bee species from before and after 1980, Biesmeijer et al. (2006) re-ported a $52 \%$ decline of solitary bees in United Kingdom, whilst data going back to the mid Nineteenth Century demonstrates that 11 species of solitary bee have become extinct in Britain, though at least one had recolonised in recent times (Ollerton et al. 2014). Evidence such as this has resulted in 11 solitary bees belonging to the genera Osmia, Nomada, Colletes, Andrena, Lasioglossum, Eucera and Anthophora being listed as targets for conservation action (Natural England 2013).

Our understanding of urban bee ecology is limited. In a review, Hernandez et al. (2009) found only 59 research publications worldwide on urban bee ecology and concluded that we are only beginning to 
document urban bee communities and their dynamics. The interest in urban bee ecology has surged in recent years (Everaars et al. 2011; Winfree et al. 2011; Hennig and Ghazoul 2012; Banaszak-Cibicka and Zmihorski 2012; Hinners et al. 2012; Matteson et al. 2013; Verboven et al. 2014; Lowenstein et al. 2014; Baldock et al. 2015). However urbanisation is predicted to increase dramatically, with the number of people living in urban areas reaching 5 billion by 2030 (UN 2011). The expansion of the physical extent and increased density of the urban setting is occurring more rapidly than the increase in urban populations (Elmqvist et al. 2013), therefore more land will be used and reused to accommodate urban growth. Urbanisation can affect bee species in different ways, depending on the guilds to which they belong (Liow et al. 2001; Fetridge et al. 2008) and may increase or decrease bee species richness depending on variables such as taxon, spatial scale of analysis, and intensity of urbanisation. However in their reviews, Hernandez et al. (2009) and Winfree et al. (2011) suggested that overall urbanisation has a negative impact on bee species richness

Urbanisation can eliminate resources (Czech et al. 2000) and replace previous native habitats with a mosaic of buildings, parks, pavements, gardens and small spontaneous vegetation patches (French et al. 2005; Johnson and Klemens 2005). However, gardens and small weedy patches are also considered to have biodiversity value in urban habitat studies (Matteson et al. 2008; Sarah and Jeremy 2012; Larson et al. 2014; Maclvor et al. 2014), providing refuge, food and apposite habitats to various species (Gilbert 1989). These habitats may be diverse in nectar and pollen producing flowers and hence support a variety of pollinating insects (Harrison and Davies 2002; Maclvor et al. 2014; Larson et al. 2014) and also provide nesting resources for bees (Cane et al. 2006).

Although research has shown that urbanisation may have overall negative effects on the abundance and diversity of bees (Fetridge et al. 2008; Hernandez et al. 2009; Winfree et al. 2011; though see Baldock et al. 2015), every urban area has a unique developmental history, and more research is needed to discover whether these findings are more widely applicable. In this study we report the diversity and abundance of solitary and primitively eusocial bees in churchyards, gardens, roadsides and spontaneous vegetation patches within a $500 \mathrm{~m}$ radius of the centre of a large English town, compared with the nearby meadows and orchards located on the fringes of the town.

The study was conducted in the urban core of Northampton town $\left(52^{\circ} 14^{\prime \prime} 53^{\prime \prime} \mathrm{N}, 0^{0} 53^{\prime \prime} 49^{\prime \prime} \mathrm{W}\right.$ ) situated in the county of Northamptonshire, England (Fig. 1). We selected a $500 \mathrm{~m}$ radius from the geographical centre of the town which comprises an area of largely solid surface and limited areas of vegetation. A further eighteen sites were selected within the $500 \mathrm{~m}$ radius on the basis of accessibility (Table 1). As a comparison to the urban study six reference sites were selected within Northampton and its fringes which com-prised local nature reserves, meadows and orchards (Table 1), which are close enough 
(1600-5000 $\mathrm{m}$ from the centre) to share a similar local climate. The reason for selecting a comparatively higher number of urban sites was to include a wide range of habitats that represent urban vegetation such as churchyards, gardens, traffic roundabouts, road verges and spontaneous vegetation patches.

Bee surveys were conducted during 2012 from the first appearance of solitary and primitively eusocial bees in March and continued until October. All surveys took place between 10 a.m. and 5 p.m., on warm and sunny days (Cane et al. 2000). Two methods, hand netting (30 min/ site/survey) and pan traps ( 3 pan traps for $7 \mathrm{~h} /$ site/survey), were used in bee surveys to avoid any biases in catching specific species (Toler et al. 2005; Roulston et al. 2007; Grundel et al. 2011). The sites were divided into two sampling groups, each containing 9 urban and 3 reference sites, and surveyed every week with one or the other method. The order of site visits was randomised to ensure that all sites would receive roughly equal morning and afternoon sampling. High frequency surveys throughout the season are particularly important to record rare species and species that are active over a short period (Magurran and McGill 2011; Banaszak et al. 2014). The 15 days of observation (hand net plus pan traps) was combined to make a single sampling unit for analysis. The species that could not be identified in the field were collected in glass tubes and brought to the laboratory for identification. The individuals were killed with ethyl acetate and preserved for future reference. Bee species were identified using test keys from George Else and further confirmed/corrected by Mike Edwards.

For analysis of emergence and flight time of species, each month was divided into four quarters (Table 2). Each quarter consisted of 7 or 8 days, referred as "'a week". The pan traps and hand netting observations were pooled in each relevant week as per dates of observations. The bee collection was started at the beginning of March. In the first week of March 2012 pan traps were installed but no bee individual was caught therefore we assumed that solitary and primitively eusocial bees were not in flight in that week or prior to it.

A Mantel test was performed to observe the spatial autocorrelation in data using the geographical distance and similarity matrix (Morisita Horn index) among the 18 urban sites. The Mantel test was carried out utilizing XIstat software (Addinsoft 2014) and did not reveal autocorrelation (Mantel test, $r=0.07, p=0.18$, number of permutations $=1000$ ). Rarefaction curves were calculated (Colwell et al. 2004,2012 ) to estimate true species richness in urban and reference sites using the statistical software EstimateS 9.1 (Colwell 2013), with the data extrapolated up to 1000 samples to check the total expected number of species that had not been recorded. The species diversity among the sites was quantified by Simpson's diversity index (D) (Magurran 2004) which uses the following formula: 


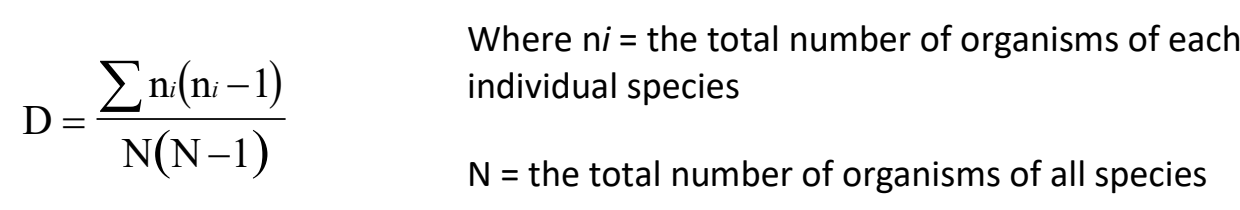

Data were further analysed using SPSS 20 for Windows. Data were shown to be non-normally distributed using the Kolmogorov-Smirnov and Shapiro-Wilk test; therefore non-parametric tests were used for data comparison. Our data had a 3:1 ratio of urban to reference site surveys so to avoid any bias from unequal sampling we randomly selected samples using a random selection option in SPSS, to give a sample of urban sites equal to reference sites before comparing these sites. The MannWhitney U test (Fowler et al. 1998) was used to compare bee abundance, species richness and species diversity (Simpson's index) in urban and reference sites. The Kruskal-Wallis test (Fowler et al. 1998) was used to look for differences between sampling areas within urban and reference sites.

\section{Results}

A total of 3836 solitary and primitively eusocial bee individuals were found during the period of sampling, 3294 in the urban sites and 542 in the reference sites. Only $3.4 \%$ of observed bees could not be identified, because of their condition following pan trapping. The remaining $96.6 \%$ were identified to at least genus level, with $93.8 \%$ of the total number of individuals identified to species level. Bees of 48 species belonging to 14 genera in 5 families were identified (Table 3). The family Andrenidae (12 spp., $38.8 \%$ of total individuals) was present in all urban and reference sites and found to be the most abundant family, followed by Megachilidae (10 spp., 19.6 \%), Halictidae (10 spp., 18.6 \%), Apidae (12 spp., $16.4 \%$ ), and Colletidae (4 spp., $6.5 \%$ ).

All documented species were recorded at least in one urban site, and $37.5 \%$ of the species were observed in $\geq 50 \%$ of urban sites. Although $19 \%$ of total recorded species in urban sites were not found at any reference sites, $48 \%$ of the total species inventory (and $59 \%$ of those recorded in reference sites) were found at 3 or more reference sites. Only $19 \%$ of the species were represented by $<10$ individuals, of which 5 species were only recorded in at least one of the urban sites which includes the singletons of Coelioxys quadridentata, Andrena chrysosceles and Nomada ruficornis. The species inventory was dominated by ground nesting species and their cleptoparasites in urban (75\% spp., 26 soil nesting species and 10 cleptoparasites, of 48 species in total) and reference sites $(76.9 \%$ spp., 24 soil nesting species and 6 cleptoparasites, of 39 species in total). In contrast, only $25 \%$ (12 
spp. of 48 in total) and $23 \%$ (9 spp. of 39 in total) of cavity nesting species were recorded in urban and reference sites, respectively. The proportion of solitary and primitively eusocial species was more or less equivalent in urban (52.1\% solitary, $27.1 \%$ eusocial) and reference sites (53.8\% solitary and 30.8 $\%$ eusocial).

The bees started flying in the second week of March. Ten species of families Andrenidae, Apidae and Halictidae appeared at various sites during this first week of emergence. The number of species in flight continued to increase until mid May. The period of late spring and early summer was the richest in bee diversity where 30-39 species were observed in flight (Fig. 2). A little more than half (53\%) of the total observed species emerged in the first month (Fig. 2). The new species continued emerging until July, with no new species spotted in the months of August, September and October. Overall, a relatively higher number of species were observed in urban areas as compared to reference sites (Fig. 3). Many bee species were seen 1 or 2 weeks earlier in urban sites compared to reference sites. In the first week of emergence, no bees were observed at the reference sites compared with 10 species in urban sites. Later, in second week of emergence, five species were observed in flight at the reference sites compared with 13 species in urban sites.

The highest bee abundance was observed in the spring (March-May) and was dominated by the genus Andrena. The highest number of species (39 spp.) was active in this season but many of these species were also recorded in summer with a total of 38 species in flight. Andrena bicolor, was present in all urban and reference sites and was the most widespread. The most abundant species was Osmia bicornis which was observed in all urban and most $(67 \%)$ of the reference sites. Megachile centuncularis, Hylaeus communis, Andrena flavipes, Lasioglossum villosulum, and Nomada fabriciana were less abundant (each species represented by $<1 \%$ of total individuals) but present in a high percentage (40-60\%) of urban sites. Individuals from the family Colletidae were also predominantly found in urban sites (15 sites) whereas this family was represented by only 8 individuals at two reference sites. At one reference site, Abington Meadow (AM), a small meadow within an urban setting, 7 individuals of Colletidae were recorded and one individual was recorded in Wilson's Orchard (WO) which bordered the urban setting. Colletes daviesanus is a species often associated with manmade walls which it uses as a substitute for cliffs as a nest site. Hence the association with urban sites is not surprising.

Substantially more species were listed in urban sites, including a few parasitic species due to their association with their hosts. For example, Melecta albifrons was recorded in $76 \%$ of urban sites due to the presence of its host Anthophora plumipes (BWARS 2013b). Over $90 \%$ of observations of $A$. plumipes were recorded in $89 \%$ of urban sites. This study also recorded the sporadic appearance of 
Nomada species in urban sites, a genus that parasitises the Andrena group (BWARS 2013c). The species found only in urban sites are presented in Fig. 4. The comparison of species richness and abundance between urban and reference sites revealed the family Andrenidae and Apidae were widely distributed across both types of site, whereas the families Colletidae, Halictidae and Megachilidae were found to be significantly different in urban and reference sites (Table 4).

Rarefaction analysis showed we sampled effectively, with the accumulation curve beginning to plateau for urban sites and reference sites (Fig. 5). The curve rises rapidly in the beginning due to the appearance of a high number of species in the spring when we started sampling. We extrapolated results up to 1000 samples in urban and reference sites to check for potential species which had not been recorded. This showed a slight continuous increase in the curve for urban sites and an estimated 55 expected species (5.7 SD, in 1000 samples) against 48 observed. In contrast, for the reference sites the extrapolated curve plateaued after 1340 individuals estimating 41.2 expected species (with 2.4 SD, in 252 samples) against 39 observed.

The survey results revealed that the mean bee diversity and abundance were higher in urban sites (Table 5). The Mann-Whitney $U$ test showed that the wild bee abundance $(U=3442$, df 181, $p<0.05)$ and diversity (Simpson's Index, $\mathrm{U}=3075$, df $181, \mathrm{p}<0.01\}$ were significantly different between urban and reference sites. In contrast, average species richness did not differ significantly between urban and reference sites $(U=3543, d f 181, p=0.08)$. Following the Kruskal-Wallis test for differences among urban and reference sites, solitary bee abundance $\left(x^{2}=48.6, \mathrm{df}=17, \mathrm{p}<0.01\right)$, species richness $\left(x^{2}=\right.$ 46.7, $\mathrm{df}=17, \mathrm{p}<0.01\}$ and species diversity (Simpson's Index $\}\left(x^{2}=30.9, \mathrm{df}=17, \mathrm{p}<0.05\right)$ were shown to vary among the urban sites. In contrast, reference sites were not found to be significantly different from each other in bee abundance $\left(x^{2}=7.6, d f=5, p=0.17\right)$, species richness $\left(x^{2}=8.8, d f=5, p=0.11\right)$ and diversity $\left(x^{2}=5.6, d f=5, p=0.34\right)$. This tells us that there is more local assemblage diversity amongst urban than reference sites.

\section{Discussion}

The limited studies published present a blurred image of the status and activities of solitary and primitively eusocial bees in urban settings in Britain because of differences in goals, methods and study sites for research. For example, some studies focused on gardens only (Smith et al. 2006; Owen 2010). Owen (2010) recorded biodiversity of a garden for about 30 years; the study produced comprehensive inventories but included only a single garden so it is impossible to know if it is representative of urban habitats. Michael (2009) assessed observations of solitary bees and wasps recorded from the 1970s onwards in woodlands, gardens and derelict sites of urban Sheffield. The use 
of Malaise traps to census bees in those studies was a commonly used method (and also used in Owen 2010) but every recording method has its flaws and Malaise traps are less effective in recording some taxa of wild bees, such as Halictidae and Apidae (Joshua et al. 2007). Therefore a combination of methods is recommended to produce a comprehensive inventory of solitary bees (Grundel et al. 2011). More recently Baldock et al. (2015) compared pollinator assemblages using flower visitation networks in urban, farmland and nature reserve landscapes across 12 British towns and cities. Although they found no overall differences in species richness and individual abundance of pollinators between these landscapes, as far as solitary bees are concerned the study was limited in that surveys did not begin until late May, missing the emergence of many early species. Comparison of these studies with our findings is therefore difficult, though it is clear that urban settings can host significant diversity and abundance of solitary and primitively eusocial bees and other pollinating insects. Considering the previous literature and goals of this study, to produce a comprehensive inventory of an urban setting, we studied a highly urbanised area and surveyed using combined methods in all months when bees were active. In this study, we did not group sites into categories or habitats such as gardens or road verges, because (a) our aim was to assess the diversity of solitary and primitively eusocial bees in the town centre, therefore we tried to include all possible habitat types which attract bees; and (b) the study area is highly built-up therefore was also not possible to have many replicates of similar habitat types in some cases.

Recording species richness is crucial for effective conservation of biodiversity. This study recorded about $22 \%$ of the total species and $58 \%$ of the total genera of solitary and primitively eusocial bees of the UK within a $500 \mathrm{~m}$ radius of a highly urbanised central town area, demonstrating the potential of urban settings for conservation of bees. Despite differences in methods and size of study sites, our species richness results are comparable with other studies of urban areas (Table 6). The noteworthy higher number of species listed by Michael (2009) in Sheffield reflected the wider range of sites where bees were recorded Lasioglossum smeathmanellum in urban sites, because of their nesting habit in the soft mortar of building walls. As noted above, similar reasoning explains the association of Colletes daviesanus with urban sites.

However, every urban setting has a unique developmental history that has influenced building heritage, microenvironments and survival of remnant habitats. Therefore, the history and geography of a town or city will consequently have an impact on the possible assemblages of solitary and primitively eusocial bees. Many bee species are confined to a particular geographical range. For example, Lasioglossum fratellum, the most common species recorded in the urban study in Sheffield by Michael (2009), was not observed in our study in Northampton. This may be primarily because $L$. 
fratellum is mainly found in northern areas, though also associated with acidic sites in southern England. In contrast, Lasioglossum morio was found to be common in this study but was not present in the species list of Michael's (2009\} study in Sheffield, perhaps because it is much more rare in northern England.

The species of family Colletidae were found associated mainly with urban sites, with few individuals found in reference sites. The latter were located at urban fringes bordering the residential areas or in some cases (Bradlaugh Fields and Abington Meadow) surrounded by houses. This produced a mosaic of urban features with natural sites at a broader scale, allowing pollinating insects to commute to the surrounding landscape in search of resources. Goddard et al. (2010) suggested that various floral patches including gardens and parks could be considered as contiguous resources by insects. Therefore, it is likely that those species living in the urban gardens benefit from the neighbouring meadows and nature reserves.

We recorded relatively higher numbers (36.7 \% of total records) of individuals of Andrenidae in urban areas. This family largely consists of ground nesting species that are seen foraging in spring. A high abundance of this family was also recorded in the city of Poznan, Poland (Banaszak-Cibicka and Zmihorski 2012). In contrast, a few studies (e.g. Matteson et al. 2008; Owen 2010) reported a low diversity of Andrenidae in urban settings. Scarceness of these species probably reflects the insufficient food resources in spring (Matteson et al. 2008). Moreover, these studies were limited to urban gardens, whereas our study found that $60 \%$ of Andrenidae records (from 6 of 18 of urban sites) were from wild patches or road sides with abundant wild flowers, particularly dandelion (Taraxacum officinale agg.). From the recorded flower-bee interactions, we observed $66 \%$ of Andrenidae foraging on dandelion flowers, while the rest (33\%) were found on 15 different plant genera in urban sites. This confirms Perkins's (1919) observations of an association between Andrena and habitats containing abundant dandelion flowers in Britain. However, these early spring species often forage at garden fruit trees (Perkins 1919). Our garden sites had a few fruit trees but our search for bees was limited to accessible parts of gardens such as lawn (where present), flower beds, and shrubs. Foragers on trees out of our visual range would have not been recorded unless caught in pan traps installed every week on the ground.

Our study recorded Coelioxys quadridentata, a rare cleptoparasitic species in the United Kingdom (Falk 1991). However, C. quadridentata, is flexible in host selection having many known hosts such as Anthophora furcata (Rowson and Pavett 2008; Mike Edwards unpublished data), Anthophora bimaculata (Jørgensen 1921), Anthophora quadrimaculata and Megachile circumcincta (Rowson and Pavett 2008). Our study only recorded Anthophora quadrimaculata as a possible host, and both host 
and parasite were found at the same site and time. Therefore we conclude that $C$. quadridentata was a cleptoparasite of $A$. quadrimaculata. A similar association of both species was also observed by D.B. Baker (pers. comm.) in Surrey, England. Although the habitat preferences of $C$. quadridentata are not known, flexibility in host selection of this species (Rowson and Pavett 2008) further increases the potential for its conservation in varied habitats, including urban settings.

A high abundance of bees in spring was anticipated as most bee species become active in this season (Wolda and Roubik 1986). About $75 \%$ of the flowering species in the United Kingdom produce flowers from March till June (Fitter and Peat 1994). Therefore more flower-visiting insects are to be expected in this season, which is confirmed by this study; about $50 \%$ of the species we recorded emerged in the first month of the season. Species records were dominated by the genera Andrena, Osmia and Anthophora, all of which are predominantly spring foraging taxa. Similar seasonal predictability was also observed by Tommasi et al. (2004) in urban gardens and parks of Vancouver, Canada. Though the members of various bee families were present in more than one season, these families exhibited a notable dominance in particular seasons. For example, species of Andrenidae, Apidae and Megachilidae were highly dominant in the spring season. In such taxa adults mature in summer or autumn and remain in cells during the unfavourable seasons (Michener 2007). They emerge from the cells in spring or summer and construct new nests. Conversely in other families such as Halictidae, pupation occurs in summer (Michener 2007). The resulting adults emerge next summer and visit summer and autumn flowers; therefore most of the Halictidae species were seen in the summer season.

The urban landscape is a result of direct human activities which are reflected in the physical environment of the area. In this manmade landscape, people add maintained patches and alter the range of plants, some of which are potential bee resources. In addition, every urban area has a different economic, historical and geographical scenario, and therefore we expect a varied response of species to urbanisation (McKinney 2008). A heterogeneous urban environment will have a complex matrix of habitat and available resources and it was suggested that urban heterogeneity has a close relationship with insect diversity and abundance (Frankie and Ehler 1978; Smith et al. 2006). Moreover, floral diversity (Gaston et al. 2005; Wojcik 2011) and green areas (Hennig and Ghazoul 2012) within urban landscapes have proven to have a positive impact on bee diversity. In our study, the extent of resources available for bees varied across the urban sites. Churchyards and gardens had a different diversity of plant species depending on the gardener's choice. On the other hand the floral composition of weedy leftover patches and roadside vegetation was not only entirely different to those in churchyards and gardens, but also vegetation was mowed frequently leaving no flowers for a 
short period of time. This could have affected the bee assemblage and abundance across the urban site and will be assessed in future analyses.

Some studies have compared bee communities in urban and natural areas and documented a higher abundance and richness of bee species in natural habitats (Matteson et al. 2008; Fetridge et al. 2008). However, Kearns and Oliveras (2009) did not find species richness and abundance of bees in urban sites significantly different from those in remote areas of Boulder, Colorado. Winfree et al. (2007) found higher bee abundance in urban and suburban rather than natural forests in New Jersey (U.S.A.) and suggested a moderate level of anthropogenic disturbance can benefit many bee species. Our study found the urban landscape to have a more abundant and diverse solitary and primitively eusocial bee assemblage. However one possible reason for the high abundance of bees in urban landscapes is the presence of high floral diversity (Gaston et al. 2005; Loram et al. 2007) and heterogeneity (Gilbert 1989) which sup-ports a wide array of bee species.

Overall, our results indicate a very encouraging finding in relation to the conservation of bees in urban settings. Finding a high diversity and abundance in the urban core and a subset of that diversity in surrounding nature reserves and meadows of relatively much larger size, accentuates the ecological and conservation value of gardens and small weedy sites within British towns and cities (see also Baldock et al. 2015). Moreover, it gives a broader perspective that the urban landscape may also act as a refuge to these bees and serve as a base to disperse from into the connecting landscape. Apart from urban gardens which pro-vide diverse resources, leftover wild patches and roadsides are equally important for conservation of solitary and primitively eusocial bees, and provide different resources to managed gardens. These findings add weight to the argument that anthropogenic habitats can support pollinator assemblages that are as diverse and abundant as sites of specific nature conservation value (Tarrant et al. 2013) and contribute to the landscape-level conservation of pollinators in Britain.

\section{Acknowledgments}

We are grateful to all those who supported this study at any stage, particularly land owners, All Saints Church, St. Giles Church, Church of the Holy Sepulchre, New Testament Church, The Churches Conservation Trust (for access to St. Peter's Church\}, Northampton and County Club, Northampton Borough Council, The Wildlife Trust BCN (for access to Bradlaugh Fields, Barnes Meadow, and Kingsthorpe Nature Reserve) and South Court Environmental (for access to Abington Meadow, Child First Orchard and Wilson's Or-chard). We would also like to thank the reviewers for their helpful comments and suggestions, and Dr. Hilary Erenler for advice about species identifications and bee biology. 


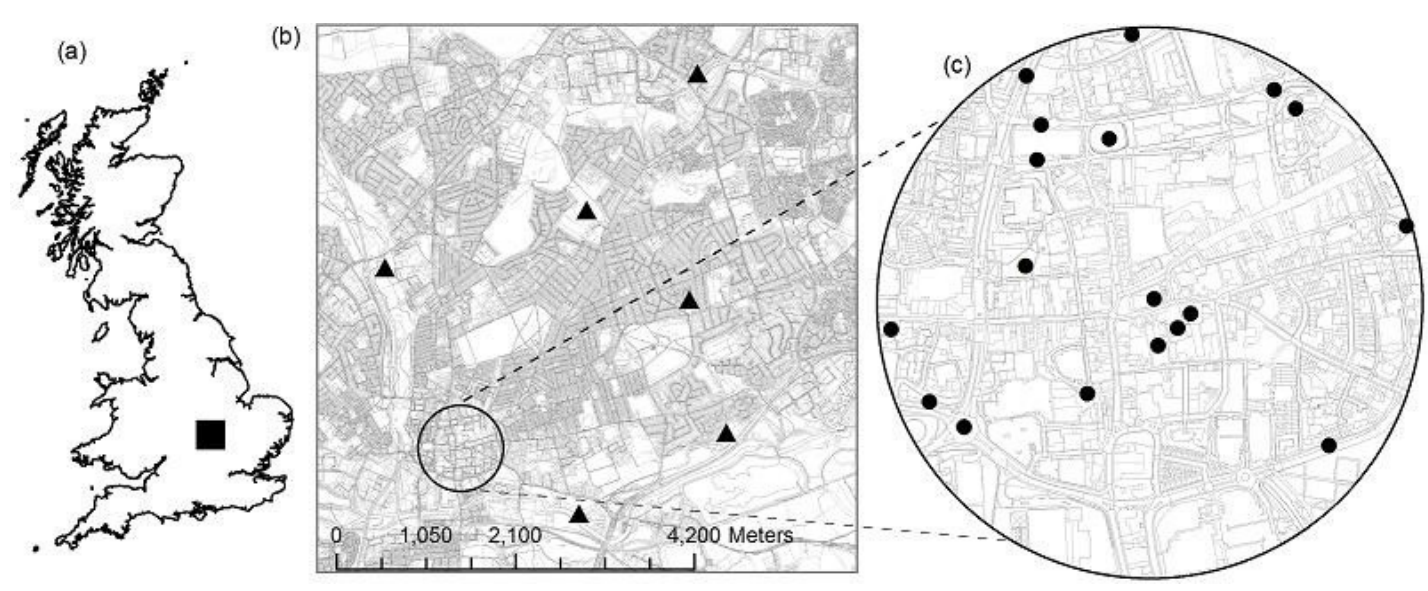

Fig. 1 Distribution of study sites: a location of Northampton in Great Britain b Northampton town, circle representing $500 \mathrm{~m}$ radius of town marked for urban sites and distribution of reference sites (triangles) in relation to town centre $\mathrm{c}$ distribution of urban sites within circle of $500 \mathrm{~m}$ radius. Data and map Crown Copyright/database right 2013. An Ordnance Survey/EDINA supplied service

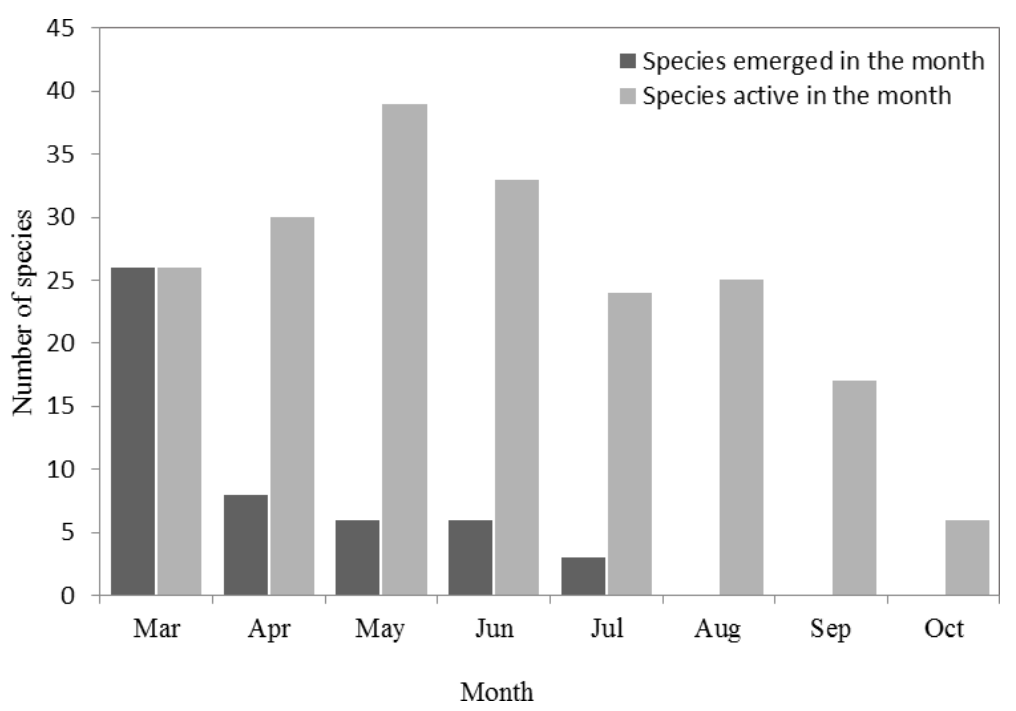

Fig. 2 Number of solitary and primitively eusocial bee species emerged and total species observed in flight during 2012. This includes the species detected in both urban and reference sites. Some species produce more than one generation in a year; for example Andrena flavipes was observed in the field from March to May and then from July to September; only the first emergence of such species is included in the figure 

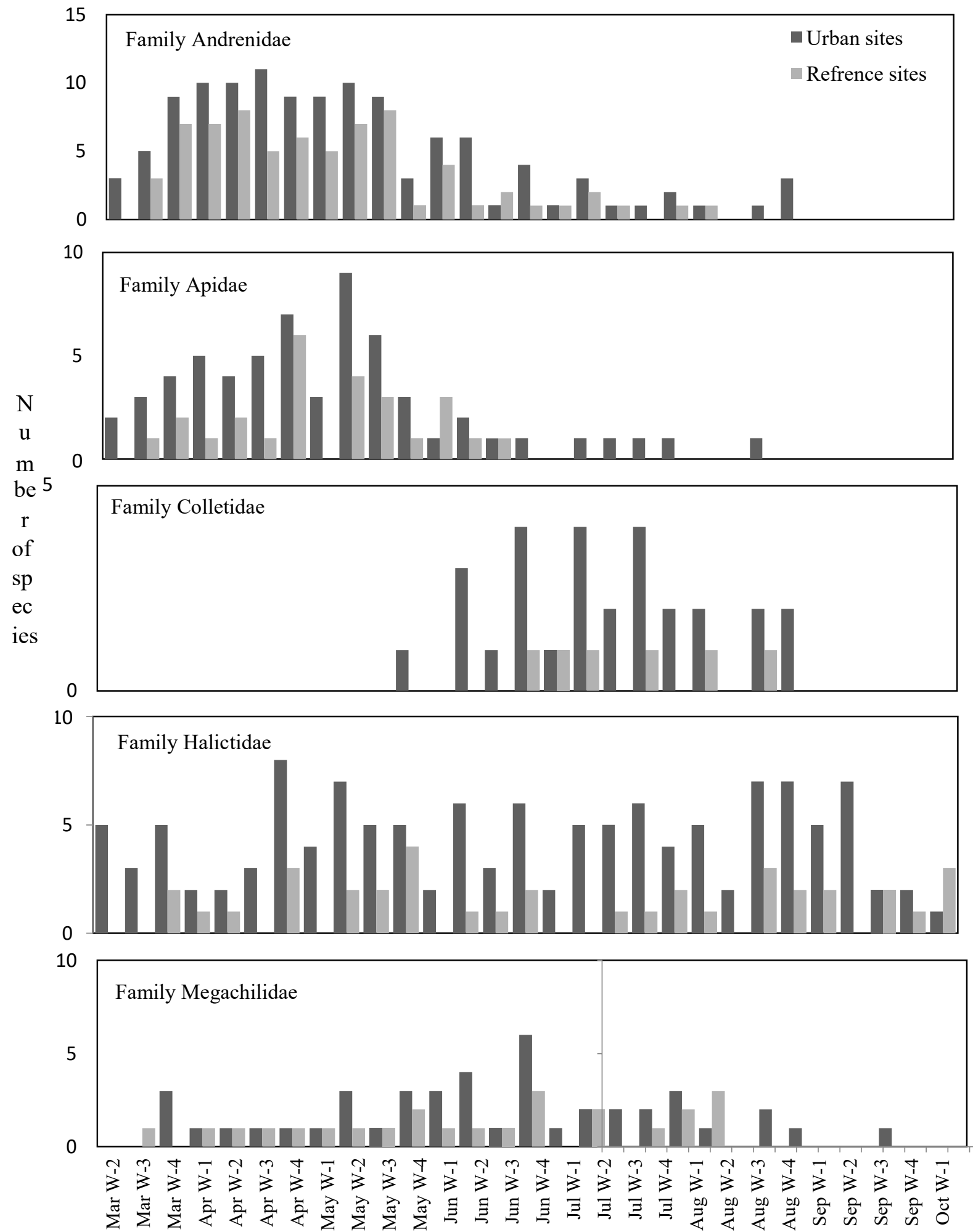

\section{Month}

Fig. 3 Number of species observed of bee families in urban and reference sites in field season 2012. (Note yaxis varies). The figure only includes the species detected in the field. We surveyed from the beginning of March to late October. No solitary bee individual was detected in the first week of March or after second week of October. 


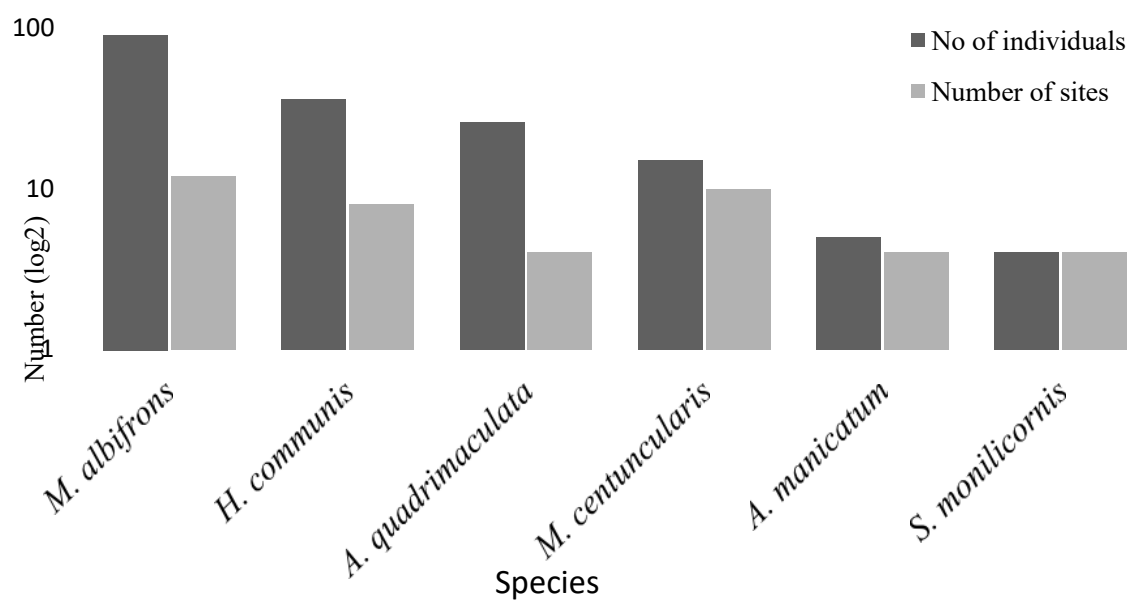

Fig. 4 Abundance and distribution of selected bee species found only in urban areas (Three species Nomada ruficornis, Andrena chrysosceles and Coelioxys quadridentata were only represented by one individual and are therefore not included)

(a)

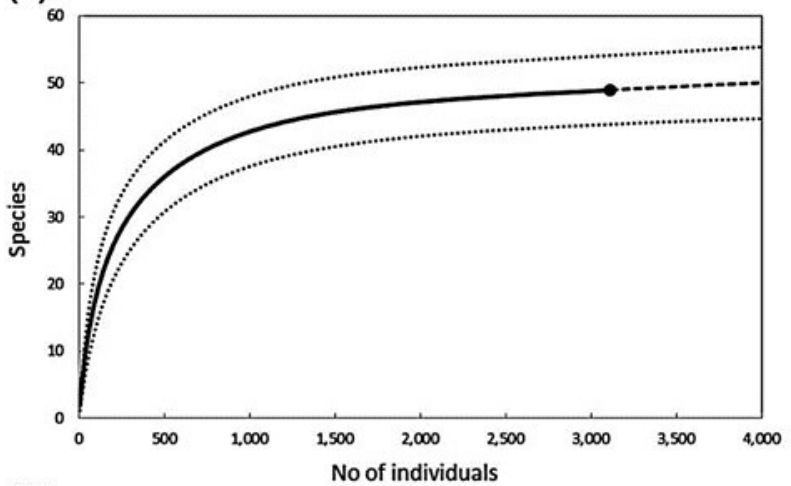

(b)

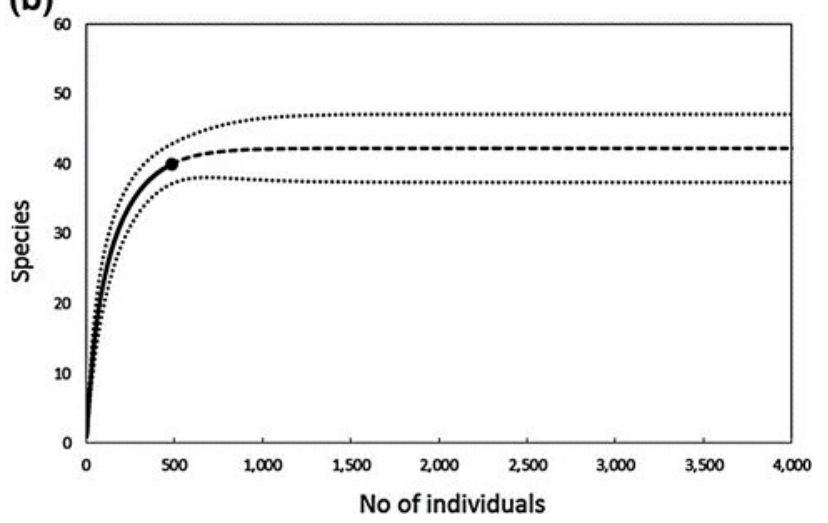

Fig. 5 Species accumulation curves using interpolation (solid curves) and extrapolation (dash curves) with $95 \%$ confidence intervals calculated using EstimateS 9.0 (Colwell 2013), species richness and individuals observed during sampling period are indicated by solid circles $a$ in urban sites and $b$ in reference sites 
Table 1 List of the sites surveyed for bees in and around Northampton, with their descriptions and size

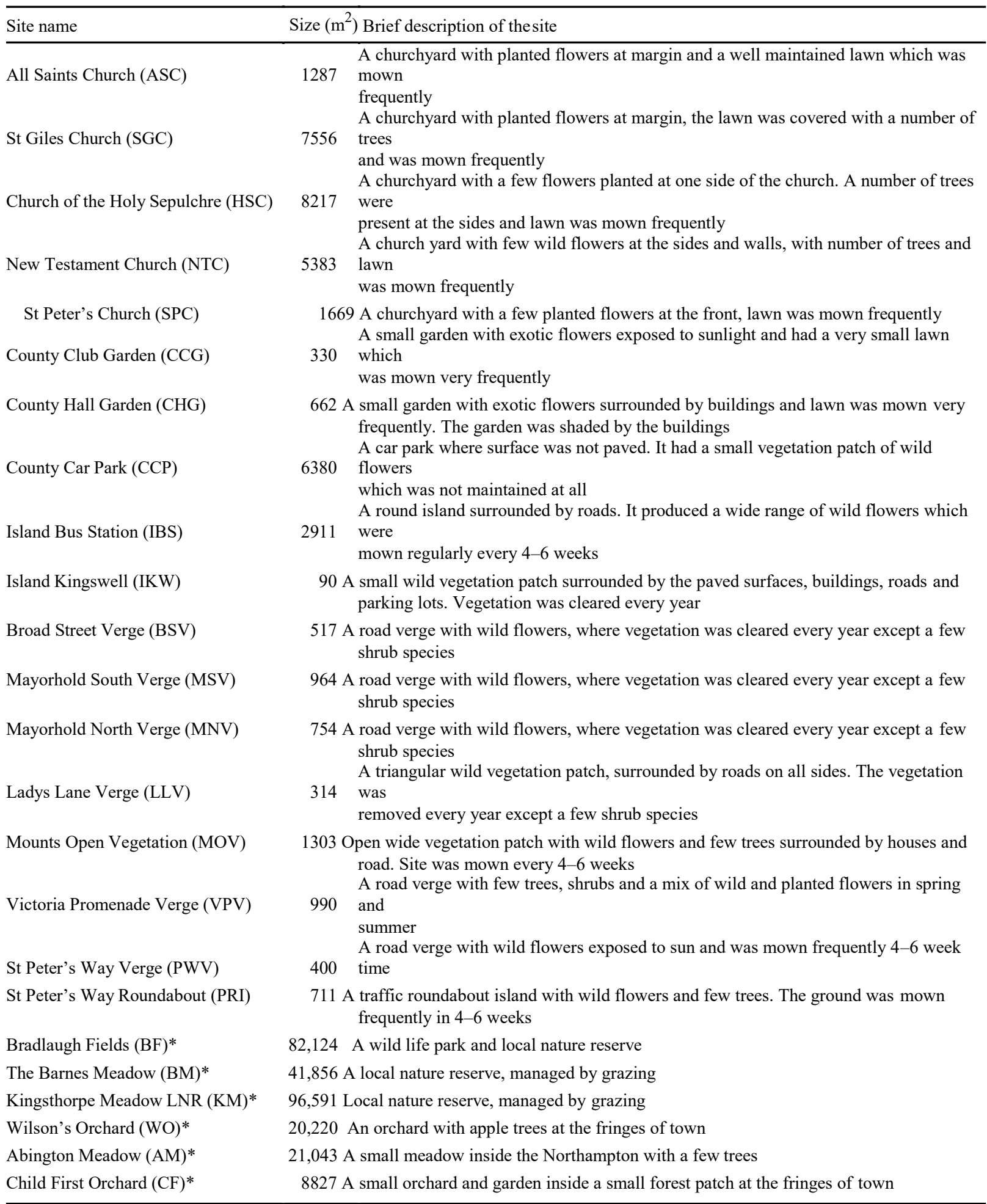

* Non-urban reference sites are marked 
Table 2 Week dates for bee sampling: each month was divided into four quarters and each quarter assumed to be "'a week'

Week one (W-1)

Week two (W-2)

Week three (W-3)

Week four (W-4)
Day 1-7 of the month (7 days)

Day $8-15$ of the month (8 days)

Day $16-23$ of the month (8 days)

Day $24-30 / 31$ of the month (7/8 days) 
Table 3 Solitary and primitively eusocial bee species collected from 18 urban and 6 reference sites in Northampton, England in 2012

\begin{tabular}{|c|c|c|c|c|c|}
\hline Species & $\begin{array}{l}\% \text { urban sites } \\
\text { where present } \\
(n=18)\end{array}$ & $\begin{array}{l}\% \text { reference sites where } \\
\text { present }(n=6)\end{array}$ & $\begin{array}{l}\text { Relative } \\
\text { abundance } \\
(\mathrm{n}=3836)^{\mathrm{a}}\end{array}$ & $\begin{array}{l}\% \text { abundance } \\
\text { urban sites }^{b}\end{array}$ & $\begin{array}{l}\% \text { abundance } \\
\text { reference site }^{\mathrm{b}}\end{array}$ \\
\hline Andrena bicolor Fabricius, 1775 & 100 & 100 & 9.7 & 88.2 & 11.8 \\
\hline Andrena carantonica Pe'rez, 1902 & 44 & 50 & 1.4 & 66.7 & 33.3 \\
\hline Andrena chrysosceles (Kirby, 1802) & 5.6 & Absent & 0.03 & 100 & Absent \\
\hline Andrena cineraria (Linnaeus, 1758) & 50 & 67 & 4.9 & 83 & 17 \\
\hline Andrena dorsata (Kirby, 1802) & 72 & 83 & 4.7 & 83.8 & 16.2 \\
\hline Andrena flavipes Panzer, 1799 & 44 & 33 & 0.9 & 73.5 & 26.5 \\
\hline Andrena fulva (Mu“"ler, 1766) & 56 & 67 & 1.4 & 73.1 & 26.9 \\
\hline Andrena haemorrhoa (Fabricius, 1781) & 67 & 83 & 2.1 & 67.1 & 32.9 \\
\hline Andrena minutula (Kirby, 1802) & 83 & 67 & 3.4 & 85.6 & 14.4 \\
\hline Andrena nigroaenea (Kirby, 1802) & 78 & 67 & 2.2 & 72.6 & 27.4 \\
\hline Andrena nitida (Mu"ller, 1776) & 89 & 83 & 5.0 & 79.6 & 20.4 \\
\hline Andrena spp. & 83 & 83 & 1.6 & 80.6 & 19.4 \\
\hline Andrena tibialis (Kirby, 1802) & 33 & 50 & 0.5 & 50 & 50 \\
\hline Anthidium manicatum Linnaeus, 1758 & 22 & Absent & 0.1 & 100.0 & Absent \\
\hline $\begin{array}{l}\text { Anthophora plumipes (Pallas, 1772) } \\
\text { Anthophora quadrimaculata (Panzer, }\end{array}$ & 89 & 100 & 8.6 & 90.9 & 9.1 \\
\hline 1798) & 22 & Absent & 0.7 & 100 & Absent \\
\hline Chelostoma campanularum (Kirby, 1802) & 5.6 & 17 & 0.1 & 50 & 50 \\
\hline Coelioxys quadridentata (Linnaeus, 1758) & 5.6 & Absent & 0.03 & 100 & Absent \\
\hline Coelioxys spp. & 11 & Absent & 0.1 & 100.0 & Absent \\
\hline Colletes daviesanus Smith, 1846 & 17 & 17 & 0.7 & 85.7 & 14.3 \\
\hline Halictus rubicundus (Christ, 1791) & 28 & 50 & 0.4 & 71.4 & 28.6 \\
\hline Halictus tumulorum (Linnaeus, 1758) & 28 & 67 & 0.4 & 58.8 & 41.2 \\
\hline Hylaeus communis Nylander, 1852 & 44 & Absent & 0.9 & 100 & Absent \\
\hline Hylaeus hyalinatus Smith, 1842 & 72 & 17 & 2.1 & 97.5 & 2.5 \\
\hline Hylaeus signatus (Panzer, 1798) & 44 & 33 & 2.5 & 97.9 & 2.1 \\
\hline Hylaeus spp. & 17 & Absent & 0.1 & 100 & Absent \\
\hline $\begin{array}{l}\text { Lasioglossum leucozonium (Schrank, } \\
\text { 1781) }\end{array}$ & 28 & 33 & 0.4 & 78.6 & 21.4 \\
\hline Lasioglossum pauxillum (Schenck, 1853) & 17 & 33 & 0.4 & 87.5 & 12.5 \\
\hline Lasioglossum albipes (Fabricius, 1781) & 56 & 50 & 1.5 & 91.5 & 8.5 \\
\hline Lasioglossum calceatum (Scopoli, 1763) & 67 & 50 & 1.8 & 95.7 & 4.3 \\
\hline Lasioglossum lativentre (Schenck, 1853) & 33 & 17 & 0.3 & 91.7 & 8.3 \\
\hline Lasioglossum malachurum (Kirby, 1802) & 33 & 50 & 0.8 & 38.7 & 61.3 \\
\hline Lasioglossum morio (Fabricius, 1793) & 78 & 67 & 6.1 & 94.4 & 5.6 \\
\hline Lasioglossum smeathmanellum (Kirby, & & & & & \\
\hline 1802) & 67 & 17 & 4.2 & 98.8 & 1.2 \\
\hline Lasioglossum spp. & 33 & 67 & 0.4 & 66.7 & 33.3 \\
\hline Lasioglossum villosulum (Kirby, 1802) & 44 & 50 & 0.6 & 81.8 & 18.2 \\
\hline Megachile centuncularis (Linnaeus, 1758) & 56 & Absent & 0.4 & 100 & Absent \\
\hline Megachile ligniseca (Kirby, 1802) & 22 & 33 & 0.3 & 33.3 & 66.7 \\
\hline Megachile spp. & 28 & 17 & 0.3 & 92.3 & 7.7 \\
\hline Megachile willughbiella (Kirby, 1802) & 17 & 17 & 0.2 & 83.3 & 16.7 \\
\hline Melecta albifrons (Forster, 1771) & 67 & Absent & 2.4 & 100 & Absent \\
\hline Nomada fabriciana (Linnaeus, 1767) & 44 & 67 & 0.5 & 76.2 & 23.8 \\
\hline Nomada flavoguttata (Kirby, 1802) & 17 & 33 & 0.1 & 60 & 40 \\
\hline Nomada flava Panzer, 1798 & 27 & 50 & 1.5 & 40 & 60 \\
\hline Nomada goodeniana (Kirby, 1802) & 67 & 67 & 1.3 & 83.7 & 16.3 \\
\hline Nomada marshamella (Kirby, 1802) & 39 & 33 & 0.4 & 71.4 & 28.6 \\
\hline Nomada panzeri Lepeletier, 1841 & 17 & 17 & 0.3 & 90 & 10 \\
\hline
\end{tabular}


Table 3 continued

\begin{tabular}{lllcll}
\hline Species & $\begin{array}{l}\text { \% urban sites } \\
\text { where present } \\
(\mathrm{n}=18)\end{array}$ & $\begin{array}{l}\text { \% reference sites where } \\
\text { present }(\mathrm{n}=6)\end{array}$ & $\begin{array}{l}\text { Relative } \\
\text { abundance } \\
(\mathrm{n}=3836)^{\mathrm{a}}\end{array}$ & $\begin{array}{l}\text { \% abundance } \\
\text { urban sites }^{\mathrm{b}}\end{array}$ & $\begin{array}{l}\text { \% abundance } \\
\text { reference site }^{\mathrm{b}}\end{array}$ \\
\hline Nomada ruficornis (Linnaeus, 1758) & 5.6 & Absent & 0.03 & 100 & Absent \\
Nomada spp. & 33 & 33 & 0.4 & 57.1 & 42.9 \\
Osmia caerulescens (Linnaeus, 1758) & 28 & 17 & 0.4 & 80.0 & 20.0 \\
Osmia leaiana (Kirby, 1802) & 28 & 17 & 0.3 & 90.9 & 9.1 \\
Osmia bicornis (Linnaeus, 1758) & 100 & 67 & 16.8 & 92.1 & 7.9 \\
Osmia spinulosa (Kirby, 1802) & 5.6 & 33 & 0.2 & 16.7 & 83.3 \\
Sphecodes monilicornis (Kirby, 1802) & 22 & Absent & 0.1 & 100 & Absent \\
\hline
\end{tabular}

The bee individuals that could not be identified to species level are recorded with relevant genus name followed by spp.

a Relative abundance of species observed in 18 urban and 6 reference sites

b Percentage of the total number of the individuals of a species observed in 18 urban and 6 reference site

Table 4. Results of Mann-Whitney $U$ test for the differences in average species richness and abundance of solitary bee families among urban and reference sites. The significant results are highlighted in bold.

\begin{tabular}{lccrr}
\hline Bee families & \multicolumn{2}{c}{ Bee abundance } & \multicolumn{2}{c}{ Species richness } \\
& $U$ & $p$ & $U$ & $p$ \\
\hline Andrenidae & 4046 & 0.76 & 3804 & 0.25 \\
Apidae & 3737 & 0.17 & 3962 & 0.56 \\
Colletidae & 3246 & $<0.01$ & 3270 & $<0.01$ \\
Halictidae & 3337 & $<0.05$ & 3435 & $<0.05$ \\
Megachilidae & 3414 & $<0.05$ & 3534 & $<0.05$ \\
\hline
\end{tabular}


Table 5 Descriptive statistics of bee abundance, species richness and diversity for the sites surveyed in 2012 (data pooled for 15 days includes $30 \mathrm{~min}$ hand netting and $7 \mathrm{~h}$ pan traps)

\begin{tabular}{|c|c|c|c|c|c|c|c|c|}
\hline \multirow[t]{2}{*}{ Sites } & \multicolumn{5}{|c|}{ Descriptive statistics } & \multicolumn{3}{|l|}{ Diversity and richness } \\
\hline & $\mathrm{N}$ & Min & Max & Mean & SD & $\begin{array}{l}\text { Simpson's diversity } \\
\text { (D) }\end{array}$ & Specie & Species richness \\
\hline ASC & 16 & 0 & 48 & 13.2 & 17.2 & 0.18 & 206 & 18 \\
\hline BSV & 16 & 0 & 199 & 5.0 & 4.8 & 0.17 & 72 & 18 \\
\hline CCG & 16 & 0 & 54 & 20.4 & 14.7 & 0.14 & 310 & 27 \\
\hline $\mathrm{CCP}$ & 16 & 0 & 34 & 10.6 & 8.5 & 0.12 & 146 & 22 \\
\hline CHG & 16 & 0 & 11 & 3.4 & 3.2 & 0.14 & 50 & 14 \\
\hline HSC & 16 & 0 & 50 & 11.3 & 16.4 & 0.08 & 175 & 21 \\
\hline IBS & 16 & 0 & 133 & 26.6 & 41.7 & 0.13 & 410 & 30 \\
\hline IKW & 15 & 0 & 62 & 18.4 & 16.0 & 0.1 & 264 & 22 \\
\hline LLV & 16 & 0 & 40 & 12.3 & 11.5 & 0.08 & 187 & 29 \\
\hline MNV & 16 & 0 & 6 & 1.1 & 1.7 & 0.18 & 17 & 07 \\
\hline MOV & 15 & 0 & 66 & 14.7 & 20.7 & 0.16 & 207 & 24 \\
\hline MSV & 15 & 0 & 34 & 12.0 & 9.7 & 0.09 & 170 & 25 \\
\hline NTC & 15 & 0 & 26 & 9.5 & 7.8 & 0.13 & 131 & 20 \\
\hline PRI & 16 & 0 & 54 & 10.7 & 17.3 & 0.14 & 163 & 20 \\
\hline PWV & 16 & 0 & 41 & 8.1 & 12.4 & 0.11 & 123 & 18 \\
\hline SGC & 16 & 0 & 57 & 14.9 & 16.8 & 0.1 & 220 & 29 \\
\hline SPC & 15 & 0 & 31 & 8.6 & 9.9 & 0.09 & 123 & 18 \\
\hline VPV & 16 & 0 & 77 & 8.9 & 20.2 & 0.29 & 139 & 13 \\
\hline $\mathrm{AM}^{*}$ & 15 & 0 & 28 & 7.8 & 7.7 & 0.08 & 102 & 29 \\
\hline $\mathrm{BF}^{*}$ & 16 & 0 & 33 & 7.9 & 9.1 & 0.06 & 116 & 26 \\
\hline $\mathrm{BM}^{*}$ & 15 & 0 & 36 & 6.2 & 11.5 & 0.1 & 91 & 18 \\
\hline $\mathrm{CF}^{*}$ & 15 & 0 & 13 & 3.7 & 5.2 & 0.34 & 49 & 09 \\
\hline $\mathrm{KM}^{*}$ & 15 & 0 & 18 & 4.7 & 1.6 & 0.11 & 58 & 13 \\
\hline WO* & 15 & 0 & 29 & 5.3 & 8.6 & 0.12 & 68 & 19 \\
\hline Urban sites & 283 & 0 & 133 & 11.64 & 8.27 & 0.077 & 3294 & 48 \\
\hline Reference sites & 91 & 0 & 36 & 5.96 & 16.99 & 0.053 & 542 & 39 \\
\hline
\end{tabular}

Diversity and richness excludes the individuals which could not be identified to species level. Sites are arranged in alphabetical order.

$\mathrm{N}=$ number of sampling units. For abbreviations see Table 1

* Reference sites are marked 
Table 6 Selected literature which recorded solitary and primitively eusocial bees from urban sites

\begin{tabular}{|c|c|c|c|c|c|}
\hline \multirow[t]{2}{*}{ Study reference } & \multicolumn{3}{|c|}{ Solitary bee No of individuals Study sites } & \multirow[t]{2}{*}{ Place } & \multirow[t]{2}{*}{ Duration } \\
\hline & species & caught & & & \\
\hline This study & 48 & 3294 & $\begin{array}{l}\text { Garden, churchyard, road sites, } \\
\text { roundabout, wild patches }\end{array}$ & $\begin{array}{l}\text { Northampton, } \\
\text { United } \\
\text { Kingdom }\end{array}$ & 1 year \\
\hline Matteson et al. (2008) & 48 & 944 & Gardens & $\begin{array}{l}\text { New York City, } \\
\text { United States }\end{array}$ & 4 years \\
\hline Michael (2009) & 69 & 590 & Garden, derelict land, woodlands & $\begin{array}{l}\text { sSheffield, United } \\
\text { Kingdom }\end{array}$ & [20 years \\
\hline Owen (2010) & 45 & 6686 & Single garden & $\begin{array}{l}\text { Leicester, United } \\
\text { Kingdom }\end{array}$ & [20 years \\
\hline $\begin{array}{l}\text { Hennig and Ghazoul } \\
\text { (2012) }\end{array}$ & 44 & 508 & Garden, roadsides, parks & Zurich, Switzerland & 1 year \\
\hline Hinners et al. (2012) & 84 & 6777 & $\begin{array}{l}\text { Grassland } \\
\text { Green areas, home Garden, }\end{array}$ & Colorado, USA & 2 years \\
\hline $\begin{array}{l}\text { Banaszak-Cibicka and } \\
\text { Zmihorski (2012) }\end{array}$ & 92 & 1809 & $\begin{array}{l}\text { botanical } \\
\text { garden, meadow, } \\
\text { Parks, cemeteries, }\end{array}$ & Pozan, Poland & 3 years \\
\hline Matteson et al. (2013) & 41 & 521 & $\begin{array}{l}\text { neighbourhood } \\
\text { blocks }\end{array}$ & New York City, USA & 2 years \\
\hline $\begin{array}{l}\text { Lowenstein et al. } \\
\text { (2014) }\end{array}$ & 32 & 368 & Neighbourhood blocks & Chicago, USA & 1 year \\
\hline
\end{tabular}




\section{References:}

Addinsoft (2014) XLSTAT, Data analysis and statistics with MS Excel. Addinsoft, NY, USA.

Baldock KCR, Goddard MA, Hicks DM, KuninWE, MitschunasN, OsgathorpeLM, Potts SG, Robertson KM, Scott AV, Stone GN, Vaughan IP, Memmott J. (2015) Where is the UK's pollinator biodiversity? The importance of urban areas for flower-visiting insects.Proc Roy Soc B 282:

http://dx.doi.org/10.1098/rspb.2014.2849

Banaszak J, Banaszak-Cibicka W, Szefer P (2014) Guidelines on sampling intensity of bees (Hymenoptera: Apoidea: Apiformes). J Insect Conserv18:651-656

Banaszak-Cibicka W, Zmihorski M (2012) Wild bees along an urban gradient: winners and losers. J Insect Conserv 16:331-343

Biesmeijer JC, Roberts SP, Reemer M, Ohlemüller R, Edwards M, Peeters T, Schaffers AP, Potts SG, Kleukers R, Thomas CD, Settele J, Kunin WE (2006) Parallel declines in pollinators and insect pollinated plants in Britain and the Netherlands. Science 313:351-354

Butchart SH, Walpole M, Collen B, van Strien A, Scharlemann JP, Almond RE, Baillie JE, Bomhard B, Brown C, Bruno J, Carpenter KE, Carr GM, Chanson J, Chenery AM, Csirke J, Davidson NC, Dentener F, Foster M, Galli A, Galloway JN, Genovesi P, Gregory RD, Hockings M, Kapos V, Lamarque JF, Leverington F, Loh J, McGeoch MA, McRae L, Minasyan A, Hernández Morcillo M, Oldfield TE, Pauly D, Quader S, Revenga C, Sauer JR, Skolnik B, Spear D, Stanwell-Smith D, Stuart SN, Symes A, Tierney M, Tyrrell TD, Vié JC, Watson R.(2010) Global biodiversity: indicators of decline. Science 328:11641168

BWARS (2013a) List of British and Irish aculeate Hymenoptera (January 2012), Bees, Wasp and Ants Recording Society.http://www.bwars.com/index.php?q=content/checklist-british-and-irish-aculeatehymenoptera-0 Accessed 15 September 2013

BWARS (2013b) Melectaalbifrons (Forster, 1771),Bees, Wasp and Ants Recording Society. http://www.bwars.com/index.php?q=bee/apidae/melecta-albifrons Accessed 10 September2013

BWARS (2013c) Nomadasignata (Jurine, 1807), Bees, Wasp and Ants Recording Society.http://www.bwars.com/index.php?q=bee/apidae/nomada-signata Accessed 10 September 2013

Cane JH, Minckley R, Kervin L (2000) Sampling bees (Hymenoptera: Apiformes) for pollinator community studies: Pitfalls of pan-trapping. Journal KansEntomolSoc 73:225-231

Cane JH, Minckley RL, Kervin LJ, RoulstonTH,Williams NM (2006) Complex responses within a desert bee guild (Hymenoptera: Apiformes) to urban habitat fragmentation. EcolAppl 16:632-644

Colwell RK (2013) Estimates: Statistical estimation of species richness and shared species from samples. Version 9. User's guide and application.http://purl.oclc.org/estimates Accessed 15 September 2013

Colwell RK, Chao A, Gotelli NJ, Lin SY, Mao CX, Chazdon RL, Longino JL (2012) Models and estimators linking individual-based and sample-based rarefaction, extrapolation, and comparison of assemblages. J Plant Ecol 5:3-21

Colwell RK, Mao CX, Chang J (2004) Interpolating, extrapolating and comparing incidence-based species accumulation curves. Ecology 85:2717-2727 
Czech B, Krausman PR, Devers PK (2000) Economic associations among causes of species endangerment in the United States. Bioscience 50:593-601

Defra (2013) The State of Natural Capital: Towards a framework for measurement and valuation. A report from the Natural Capital

Committee.http://www.defra.gov.uk/naturalcapitalcommittee/files/State-of-Natural-CapitalReport-2013.pdf .Accessed 10 September 2013

Dormann CF, Schweiger O, Arens P, Augenstein I, Aviron S, Bailey D, Baudry J, Billeter R., Bugter, R, Bukácek R, Burel F, Cerny M, Cock RD, De Blust G, DeFilippi R, Diekötter T, Dirksen J, Durka W, Edwards PJ, Frenzel M, Hamersky R, Hendrickx F, Herzog F, Klotz S, Koolstra B, Lausch A, Le Coeur D, Liira J, Maelfait JP, Opdam P, Roubalova M, Schermann-Legionnet A, Schermann N, Schmidt T, Smulders M J, Speelmans M, Simova P, Verboom J, van Wingerden W, Zobel M (2008) Prediction uncertainty of environmental change effects on temperate European biodiversity. EcolLett 11:235244

EFSA (2014)Towards an integrated environmental risk assessment of multiple stressors on bees: review of research projects in Europe, knowledge gaps and recommendations. EFSA Journal 12:3594 doi:102903/j.efsa.2014.3594

Elmqvist J, Fragkias M, Goodness J, Güneralp B, Marcotullio PJ, McDonald RI, Parnell S, Schewenius M, Sendstad M, Seto KC, Wilkinson K (2013) Urbanization, Biodiversity and Ecosystem Services: Challenges and Opportunities. Springer, New York

Everaars J, Strohbach MW, Gruber B, Dormann CF (2011) Microsite conditions dominate habitat selection of the red mason bee (Osmiabicornis, Hymenoptera: Megachilidae) in an urban environment: A case study from Leipzig, Germany. Landscape Urban Plan 103:15-23

Falk S (1991) A review of the scarce and threatened bees, wasps and ants of Great Britain. Research and Survey in Nature Conservation No. 35. Nature Conservancy Council for England, Peterborough

Fetridge ED, Ascher JS, Langellotto GA (2008) The bee fauna of residential gardens in a suburb of New York City (Hymenoptera: Apoidea). Ann EntomolSoc Am 101:1067-1077

Fitter AH, Peat HJ (1994) The ecological flora data base. JEcol 82:415-425

Fowler L, Cohen L, Jarvis P (1998) Practical Statistics for Field Biology, 2nd edition. John Wiley and Sons Ltd, Chichester

Frankie GW, Rizzardi M, Vinson SB, Griswold TL (2009) Decline in bee diversity and abundance from 1972-2004 on a flowering leguminous tree, Andirainermis in Costa Rica at the interface of disturbed dry forest and the urban environment. J Kans Entomol Soc 82:1-20

Frankie GW, Ehler LE (1978) Ecology of insects in urban environments. Ann Rev Entomol 23:367-387

French K, Major R, Hely K (2005) Use of native and exotic garden plants by suburban nectarivorous birds. Biol Cons 121:545-559

Gaston K, Smith R, Thompson K, Warren P (2005) Urban domestic gardens (II): experimental tests of methods for increasing biodiversity. Biodivers Conserv 14:395-413

Gilbert OL (1989) The Ecology of Urban Habitats. Chapman and Hall, London

Goddard MA, Dougill AJ, Benton TG (2010) Scaling up from gardens: biodiversity conservation in urban environments. Trends Ecol Evol 25:90-98 
Goulson D, Lye GC, Darvill B (2008) Decline and conservation of bumble bees. AnnRevEntomol 53:191-208

Grixti CJ, Wong LT, Cameron SA, Favret C (2009) Decline of bumble bees (Bombus) in the North American Midwest.Biol Cons 142:75-84

Grundel R, Fronhnapple KJ, Jean RP, Pavlovic NB (2011) Effectiveness of bowl trapping and netting for inventory of a bee community. Environ Entomol 40:274-380

Harrison C, Davies G (2002\} Conserving biodiversity that matters: practitioners' perspectives on brownfield development and urban nature conservation in London. J Environ Manage 65:95-108

Hennig El, Ghazoul J (2012) Pollinating animals in the urban environment. Urban Ecosyst 15:149-166.

Hernandez JL, Frankie GW, Thorp RW (2009) Ecology of urban bees: A review of current knowledge and directions for future study. Cities Environ 2:article 3http://escholarship.bc.edu/cate/vol2/iss1/3

Hinners SJ, Kearns CA, Wessman CA (2012) Role of scale, matrix and native habitat in supporting a diverse suburban pollinator assemblage. EcolAppl 22:923-1935

Johnson EA, Klemens MW (2005) Nature in fragments: the legacy of sprawl. Columbia University Press, New York

Jørgensen, P (1921) Bier.Danmarks Fauna25.G.E.C.Gads, København.

Joshua W, Campbell J, Hanula L (2007) Efficiency of Malaise traps and colored pan traps for collecting flower visiting insects from three forested ecosystems. J Insect Conserv 11:399-408

Kearns CA, Oliveras DM (2009) Environmental factors affecting bee diversity in urban and remote grassland plots in Boulder, Colorado. J Insect Conserv 13:655-665

Kevan PG, Greco CF, Belaoussoff S (1997) Log-normality of biodiversity and abundance in diagnosis and measuring of ecosystemic health: pesticide stress on pollinators on blueberry heaths. JApplEcol 34:1122-1136

Klein AM, Vaissière BE, Cane JH, Steffan-Dewenter I, Cunningham S, Kremen C, Tscharntke T (2007) Importance of pollinators in changing landscapes for world crops.Proc Roy Soc B274:303-313

Larson JL, Kesheimer AJ, Potter DA (2014) Pollinator assemblage on dandelion and white clover in urban and suburban lawns. J Insect Conserv 18:863-873

Leonhardt SD, Gallai N, Garibaldi LA, KuhImann M, Klein A (2013) Economic gain, stability of pollination and bee diversity decrease from southern to northern Europe. Basic ApplEcol 14:461-471

Liow LH, Sodhi NS, Elmquist T (2001) Bee diversity along a disturbance gradient in tropical lowland forests of south-east Asia. J Appl Ecol 38:180-192

Loram A, Tratalos J, Warren P, Gaston K (2007) Urban domestic gardens (X): the extent and structure of the resource in five major cities. Landsc Ecol 22:601-615

Lowenstein DM, Matteson KC, Xiao I, Silva AM, Minor ES (2014) Humans, bees, and pollination services in the city: the case of Chicago, IL (USA). Biodivers Conserv 23:2857-2874.

Maclvor JS, Ruttan A.,Salehi B ( 2014) Exotic on exotics: pollen analysis of urban bees visiting Sedum on a green roof. Urban Ecosyst. doi: 10.1007/s11252-014-0408-6

Magurran AE (2004) Measuring biological diversity. Blackwell, Malden 
Magurran AE, McGill BJ (2011) Biological diversity, frontiers in measurement and assessment. Oxford University Press, Oxford

Matteson KC, Ascher JS, Langellotto GA (2008) Bee richness and abundance in New York City urban gardens. Ann EntomolSoc Am 101:140-150

Matteson KC, Grace JB,, Minor ES (2013) Direct and indirect effect of land use on floral resources and flower-visiting insects across an urban landscape. Oikos122:682-69

McKinney ML (2008) Effects of urbanization on species richness: a review of plants and animals. Urban Ecosyst 11:161-176

Michael A (2009) The solitary wasps and bees (Hymenoptera: Aculeata) of the "G 'EEN SPACES' of urban Sheffield. Entomol Mon Mag 145:11-25

Michener CD (2007) Bees of the world. $2^{\text {nd }}$ edit. Maryland. The Johns Hopkins University Press

Moldenke AR (1976) California pollination ecology and vegetation types.Phytologia 34:305-361

Natural England (2013) Habitats and species of principal importance in England, Natural England.http://www.naturalengland.org.uk/ourwork/conservation/biodiversity/protectandmanage/ habsandspeciesimportance.aspx. Accessed 12 September 2013

Ollerton J, Tarrant S, Winfree R (2011) How many flowering plants are pollinated by animals? Oikos 120: $321-326$

Ollerton J, Erenler H, Edwards M, Crockett, R (2014) Extinctions of aculeate pollinators in Britain and the role of large-scale agricultural changes. Science 346:1360-1362

Owen J (2010) Wildlife of a garden:a thirty-year study. Royal Horticultural Society, Peterborough

Perkins RCL (1919) The British species of Andrena and Nomada. TransEntomolSoc London 1919: 218319

Potts SG, Biesmeijer JC, Kremen C, Neumann P, Schweiger O (2010) Global pollinator declines: trends, impacts and drivers. Trends EcolEvol 25:345-353

Rortais A, Arnold G, HalmM,Touffet-Briens F (2005) Modes of honeybees exposure to systemic insecticides: estimated amounts of contaminated pollen and nectar consumed by different categories of bees. Apidologie 36:71-83

RoulstonTH, Smith SA, Brewstera AL ( 2007) Comparison of pan trap and intensive net sampling techniques for documenting a bee (Hymenoptera: Apiformes) fauna. JKansEntomolSoc 80:179-181

Rowson R,Pavett M (2008) A visual guide for the identification of British Coelioxys bees. Privately published, Cardiff, UK

Sarah L, Jeremy T (2012) Ecosystem services provided by urban spontaneous vegetation. Urban Ecosyst 15:545-557

Simpson BB (1977) Breeding systems of a dominant perennial plants of two disjunct warm desert ecosystems. Oecologia 27:203-226

Smith RM, Gaston KJ, Warren PH, Thompson K (2006) Urban domestic gardens (VIII): environmental correlates of invertebrate abundance. BiodiversConserv 15:2515-2545 
Stout J,Morales CL (2009) Ecological impacts of invasive alien species on bees.Apidologie 40: 388409

Tarrant S, Ollerton J, Rahman L Md, Griffin J, McCollin D (2013) Grassland restoration on landfill sites in the East Midlands, UK: an evaluation of floral resources and pollinating insects. Restoration Ecol 21:560-568

Thomson DM (2006) Detecting the effects of introduced species: a case study of competition between Apis and Bombus. Oikos 114:407-418

Toler TR, Evans EW, Tepedino VJ (2005) Pan-trapping for bees (Hymenoptera:Apiformes\} in Utah's West Desert: the importance of colour diversity. Pan-PacEntomol 81:103-113

Tommasi D, Miro A, Higo HA, Winston ML (2004) Bee diversity and abundance in an urban setting. CanEntomol 136:851-869

UN (2011) World urbanization prospectus, the 2011 revision.Department of Economic and Social Affairs (Population division) United Nations report. United Nations, New York

Verboven HAF, Uyttenbroeck R, Brys R, Hermy M (2014) Different responses of bees and hoverflies to land use in an urban-rural gradient show the importance of the nature of the rural land use. Landscape Urban Plan 126:31-41

Wilson EO (1999) TheDiversityof Life. W.W. Norton and Company Inc., New York

Winfree R, Aguilar R, Vázquez, DP, LeBuhn G, Aizen MA (2009) A meta-analysis of bees' responses to anthropogenic disturbance. Ecology 90:2068-2076

Winfree R, Bartomeus I, Cariveau DP (2011) Native pollinators in anthropogenic habitats. Ann RevEcolEvolSyst 42:1-22

Winfree R, Griswold T, Kremen C (2007) Effect of human disturbance on bee communities in aforestedecosystem. Conserv Biol21:213-223

Wojcik V (2011) Resource abundance and distribution drive bee visitation within developing tropical urban landscapes. J PollEcol 4:48-56

Wolda H, Roubik DW (1986) Nocturnal bee abundance and seasonal bee activity in a Panamanian forest. Ecology 62:426-433 